\title{
MODELLING STOCK EXCHANGE INDEX RETURNS IN DIFFERENT GDP GROWTH REGIMES
}

\author{
Alenka Kavkler, Mejra Festić*
}

\begin{abstract}
:
During different GDP growth regimes, the dynamics of global financial markets impacts the Slovenian stock exchange with varying intensity. We propose a smooth transition regression model to explain Slovene stock exchange index returns employing financial and macroeconomic variables. According to our model, the reaction of the stock market to several of the explanatory variables depends on the magnitude of GDP growth. The weaker relationship between Slovene stock exchange index returns and S\&P 500 returns in the period of lower or negative GDP growth could be explained by less developed financial market in Slovenia and therefore not closely linked interchange of securities.
\end{abstract}

Keywords: GDP growth regimes, smooth transition regression, stock returns.

JEL classification: C25, F36, F47, G12, G15

\section{Introduction}

Capital markets in Central and Eastern Europe (CEE) are not very well developed, in general, stock market capitalization is relatively low and the private sector has relied more on bank finance than on stock market financing. Government paper dominates debt markets and corporate debt markets hardly exist (Baltzer et al., 2008). The earlier stage of stock markets was, as yet, characterised by the lack of adequate regulatory framework and the dominance of a small number of firms. There was also less incentive for firms to list due to the requirement of disclosure and the high cost of raising funds through the equity market. Equity markets in the EU's New Member States (NMS) have developed along two different lines (see, Wang and Moore, 2008). The banking sector has remained the most important source of external financing for firms in the New

* Alenka Kavkler, EPF - Faculty of Economics and Business, University of Maribor, Slovenia, (alenka.kavkler@uni-mb.si); and EIPF - The Economic Institute, Ljubljana; Mejra Festić, EPF Faculty of Economics and Business, University of Maribor, Slovenia; and EIPF - The Economic Institute, Ljubljana, Slovenia (mejra.festic@uni-mb.si; mejra.festic@eipf.si). 
EU Member States, while the privatization process has fostered the development of stock markets. The New EU Member States have also largely completed the ownership transformation process. They needed stock markets to raise new financing and enhance corporate governance, but both goals can be achieved through global markets. The exchanges of Central European and Baltic countries have mainly been used for the mandatory listing of shares of mass-privatized companies and for voluntary initial public offerings:

- Mandatory listing after mass privatization (the Czech Republic, the Slovak Republic, Lithuania, Bulgaria, Romania): The basic feature of this first group of markets was the transfer among investors of ownership rights to mass-privatized companies. At first these markets listed a large number of stocks, many of which were illiquid.

- Mandatory listing of minority packages during privatization (Slovenia, Estonia, Latvia, Hungary): A second type of market developed in Estonia, Hungary, Latvia, Poland and Slovenia started with a small number of stocks. Many stocks had fairly liquid trading.

- Voluntary initial public offerings (Poland): A third group of stock markets straddled these two types. All these countries had mass privatization programs, but the initial exchange of voucher shares took place off the stock exchanges.

The Czech Republic adopted mass privatization schemes, whereas Estonia, Hungary, Latvia, Poland and Slovenia established a legal framework for trading. The development of financial markets in the New EU Member States (NMS) can be attributed to early liberalization of foreign portfolio investment, and also to a stable macroeconomic environment and growth in recent years. ${ }^{1}$ Even in countries where there was rapid privatization through mass privatization methods such as voucher schemes, sound capital markets developed slowly (Claessens et al., 2005). During privatization the stock market was built around public offerings of companies whose majority ownership was sold to strategic investors. During the so-called post-privatization period the development of equity markets in many NMS was being hampered by lack of investor protection and transparent securities trading (Swan and Westerholm, 2006).

The direct effect of privatization on stock market capitalization is indeed relatively small compared to the total growth in market capitalization - a difference which is well explained by changes in political risks, thus confirming the importance of uncertainty resolution for investment.

The absence of large and active domestic institutional investors, inadequate clearing and settlement systems, the need to establish an adequate tax regime for securities, inconsistencies in the legal and regulatory framework, a lack of competition

1 Catching-up economies required investment levels that have exceeded domestic savings. They have financed a part of their investment through foreign direct investment (FDI) and the huge current account deficits have been financed by a steady increase of net-inflow of FDI, net portfolio investment and foreign currency loans. The positive impact of FDI and import of capital goods on economic growth is visible in the diversification of foreign trade structure, the increase of labour productivity and the improvement of competitiveness of the export industries (Brandmeier, 2006, pp. 396-400), improvement in the market structure and high growth rates (Breuss, 2003). Economic growth has been high and broad-based: domestic demand, boosted by a financed boom of bank lending, falling unemployment and real wage growth on the back of productivity gains, and export growth. 
in domestic financial markets and the dominance of the banking sector have been characteristics of the NMS (Festić and Repina, 2009). Stock markets in the NMS (New Member States) economies are dominated by a small number of firms. Because banking systems typically develop before stock markets, countries should focus on developing the basic infrastructure for investors' protection, contract enforcement, sound accounting standards for both credit and equity markets. Many NMS have to focus on developing the basic infrastructure for a financial system. A number of challenges confront us in the development of the capital market in the NMSs: Listing of more public companies and privatization of state enterprises to improve liquidity at the stock exchange, development of new financial products, an efficient legal and regulatory framework and a supportive macro-economic policy, financial environment and investor education.

In many NMS countries, high inflation, large-scale expropriation and defaults, and limited trust in contracts and institutions discouraged people from investing in any financial assets (Boyd, Levine and Smith, 2001). As required in the process of enlargement, the regulatory environment is being harmonized towards EU standards, which has helped faster development (more in, Boyd et al., 2001; Pistor et al., 2000).

In functioning market economies stock markets serve as a basic tool for ensuring efficiency of investments by providing investors with a mechanism for transferring ownership of companies and in the process revaluing them as new information on future prospects reaches the market. In this sense, legal protection of property rights in general and shareholder rights in particular, promote informed arbitrage in stocks and encourage the development of efficient stock markets. Initially, liquidity of newly established stock markets was relatively low and trading was thin with the result that in the early days at least, markets tended to be open for only one or two days a week (Harrison and Moore, 2009). Consequently, stock prices were volatile compared with developed stock markets and it seems likely that this inhibited the growth of trade because of the increased risk.

The NMS could be divided into three groups (Claessens et al., 2005) according to the access to capital markets: (i) In Poland, Hungary and the Czech Republic the markets are dominated by government paper, and lending to the corporate sector through either bank loans or international bond issues is important. Increased confidence in domestic markets is likely to lead to the emergence of corporate bond markets. Markets in Poland, Hungary and the Czech Republic will develop further with demand growing as savings as well as financing techniques become more refined. (ii) The Baltic States, where quick integration into the Nordic financial "sphere" has been facilitated by Nordic banks' acquisitions, resulting in the de-listing of domestic banks from the domestic stock exchanges. In the Baltics, where financial market integration has been facilitated by acquisitions of financial institutions by Nordic banks, better access to financing has been available with accession to the EU. (iii) The last category, which consists of the remaining transition countries, where, apart from some illiquid government bond markets, there are either no meaningful markets.

Driven by the process and prospects of EU integration, they see their domestic markets merge with bigger European exchanges. There are reasons to believe that returns in the former transition economies of CEE might, at least to some extent, be correlated with each other. All CEE economies have now reined back inflation. They 
have also adopted some form of fixed exchange rate and most of their currencies are tied to the euro. They have all created functioning stock markets with rules similar to those in developed economies. Furthermore, as transition has progressed, the economies of CEE have gradually integrated into the world. ${ }^{2}$

Stock market developments in NMS cannot be analyzed without reference to global developments. Driven by the process and prospects of EU integration, the stock markets of NMS are likely to merge with bigger European exchanges. The problems caused by the globalization of capital flows with decreasing capital controls had created a new source of instability in a form of pro-cyclical financial markets movements (more in Bae, Karolyi and Stulz, 2003). This problem was highlighted by Asia in 1997, the crisis in Russia, Latin America and United States as well in Europe in 2008. Also, the stock return correlations are not constant through time and they depend on macroeconomic fundamentals like cyclical movements, the growth rates of the gross domestic product, the level of integration etc. (Goetzmann, Li and Rouwenhorst, 2005). Most of the world's leading economies felt during 2008 into a recession period, mainly due to the emergence of the global financial downturn. This has lead to an increase in the volatility levels on stock markets.

In this article, we tested the impact of the macroeconomic fundamentals of the global economy on the Slovenian stock exchange index. We have proposed a nonlinear model for predicting future Slovene stock exchange index dynamics.

This paper is organized in the following manner. In the second chapter, we provide a brief overview of the latest studies of financial market integration, co-movements of stock exchange indices and cyclicality. In the third chapter, we discuss the methodology of smooth transition regression, the results for Slovenia in the fourth chapter, while illuminating its implications are explained in the fifth chapter.

\section{Integration of Financial Markets and Pro-Cyclicality}

With growing globalization of economies, the international capital markets are also becoming increasingly integrated. While such integration is positive for global economic growth, the downside risk is the contagion effect of financial crisis, especially if its origin lies in the bigger markets. A large number of theoretical and empirical studies are attempting to explain how financial market shocks get transmitted across countries through contagion effect and spillovers. Most New Member States liberalized their domestic markets and external regimes and they become increasingly integrated with the world economy and they become a subject of external shocks.

A variable that is positively correlated with an indicator of the overall state of economy is said to be pro-cyclical with respect to this indicator. One of the most often used indicators is economic growth. The majority of studies have confirmed that GDP/ export/gross fixed capital formation growth is a major challenge to stock exchange index returns and the dynamics of stock exchange index returns have been shown to be

2 Chelley-Steeley (2005) finds evidence that stock markets of Hungary and Poland especially, and the Czech Republic to a lesser extent, are becoming more integrated with western (France, Germany, Japan, UK and US) markets. On the other hand, Gilmore et al. (2008) find little evidence of increasing integration between the equity markets of the Czech Republic, Hungary and Poland with Germany and the UK. 
pro-cyclical with respect to economic growth. Periods of economic growth and strong demand for a country's exports have a positive effect on the domestic, corporate and household sectors and on stock exchange index returns (Borio et al., 2001). The extent to which financial system is inherently pro-cyclical coincides with the perceptions of equities' value moving up and down with the economy (Borio and Lowe, 2002).

Moreover, this pro-cyclicality then interacts with the real economy in ways that can amplify economic fluctuations (Goetz, 2004). This interaction could explain capital crunches, financial instability, banking crises, and stock exchange crises - either as fundamental or as self-fulfilling outcomes (Bernanke, 1983).

Further we cite the overview of the studies related to Central and Eastern European Economies and euro area Member States regarding the financial market procyclicality and integration.

Shocks to the Russian stock market Granger caused movements in the Czech, Hungarian and Polish stock markets and other New Member States (Gelos and Sahay, 2000) beyond standard macroeconomic linkages. There may be global shocks that simultaneously affect various countries, such as movements of USA interest rates. Also the interpretation of contagion is related to relevant fundamental financial variables linkages across countries (more in Gelos and Sahay, 2000). According to Harrison and Moore (2009) there has been a relatively weak correlation between stock markets in CEE countries and those in Europe before 2002. However, the link between the exchanges has strengthened since 2002. This finding is robust to changes in the reference stock exchange.

Harrison and Moore (2009) proved that with the exception of the Czech Republic, Hungary and Poland, there is a relatively weak correlation between daily returns in CEE countries and those in Europe. These results suggest that although the exchanges may be experiencing similar shocks, and therefore have similar fluctuations in daily returns, the equity prices are not consistently drifting towards those in the major European exchanges. Gilmore et al. (2008) claim that equity prices on Bulgarian, Latvian and Lithuanian exchanges seem to be converging to those on the DAX and FTSE, but there was little or no evidence of equity price convergence for Estonia, Romania and Slovenia. Wang and Moore (2008) explore the dynamic conditional correlation between the emerging stock markets of the Czech Republic, Hungary and Poland versus the Eurozone stock market. The overall results reveal that there have been shifts towards an increased correlation and its fluctuation during external financial crises and entry to the EU. Westermann (2004) empirically showed that the introduction of the euro shifted the linkage across the eurozone stock markets. Kim et al. (2005) find that increased stability and higher levels of integration have emerged in the post-euro era.

Dvorák and Podpiera (2006) examined a rise in stock market prices in the accession countries following the announcement of European Union enlargement. Cappiello et al. (2006) carried out an analysis of returns on equity market indices and the results suggested that integration of the New EU Member States with the euro area increased during the process of EU accession. Bechev (2003) tested the efficient market hypothesis for the stock exchanges of the Czech Republic, Hungary and Poland. The analysis confirmed that the stock exchanges did improve their efficiency, suggesting that economic fundamentals dominated the markets' decline. A study of co-movements between stock markets in Central and Eastern European countries (CEECs) on the one 
hand, and between the CEECs and Western European countries on the other hand was also the subject of research by Égert and Kočenda (2005).

Evidence of stock market integration among NMS, especially those in Central and Eastern Europe (CEE), was noted by Babetskii et al. (2007). The authors found evidence of respective stock-market integration on both national and sectoral levels between the Czech Republic, Hungary, Poland and the euro area. Černý (2004) found that the stock markets in Warsaw and Prague do react to price fluctuations stemming from the stock market in Frankfurt, not vice versa. Horská (2005) argues that the correlation among the Czech, US, and European stock markets increased over time, while restricting the room for portfolio diversification. Syllignakis and Kouretas (2006) discovered evidence of co-integration among the stock markets of the Central Eastern European countries relative to Germany and the USA. An application of generalized autoregressive conditional heteroscedasticity (GARCH) analysis to stock market indices in the CEE region was reported by Égert and Kouba (2004), confirming that stock markets in the CEE region displayed more asymmetry than the G-7 countries. Moore and Wang (2007) considered the volatility of five New EU Member States' stock markets through a regime switching model.

Christiansen et al. (2008) analyzed the financial integration of the New EU Member States' stock markets using a multinomial logit model to investigate how persistence, asset classes, and volatility are related to co-exceedance variables. Anatolyev (2007) developed and evaluated sequential testing tools for a class of nonparametric tests for predictability of financial returns that includes, in particular, the directional accuracy and excess profitability tests - focusing on linear monitoring boundaries that are continuations of horizontal lines corresponding to retrospective critical values. Chelley-Steeley (2005) used smooth transition regression model for the CEE and proved that the correlation between stock markets in the CEE has increased from 2001 to 2007.

In our empirical analysis, we used the smooth transition regression model, as can be seen in the following chapters.

\section{Smooth Transition Regression (STR) Models}

The description of STR models in this section was adapted from the paper by Teräsvirta (1998). Mathematical symbols are written in italics and vectors in bold fonts.

Many elements in economic theory promote the idea that the economy behaves differently if values of certain variables lie in one region rather than in another, or, in other words, follow different regimes. The first attempt at modelling such phenomena is represented by discrete switching models, where a finite number of different regimes is assumed. The central tool of this class of models is the so-called switching variable that can be either observable or unobservable. Since a smooth transition between regimes is often more convenient and realistic than just sudden switches, Chan and Tong (1986) have proposed a generalisation of discrete switching models in the following form:

$$
y_{t}=\mathbf{x}_{\mathbf{t}}^{\prime} \boldsymbol{\varphi}+\left(\mathbf{x}_{\mathbf{t}}^{\prime} \boldsymbol{\theta}\right) G\left(\gamma, c ; s_{t}\right)+u_{t}, t=1,2, \ldots, T .
$$

where $\boldsymbol{\varphi}=\left(\varphi_{0}, \varphi_{1}, \ldots, \varphi_{p}\right)^{\prime}$ and $\boldsymbol{\theta}=\left(\theta_{0}, \theta_{1}, \ldots, \theta_{p}\right)^{\prime}$ are the parameter vectors, $\mathbf{x}_{\mathbf{t}}$ is the vector of explanatory variables containing lags in the endogenous variable and the exogenous variables, $\left(i . e . \mathbf{x}_{\mathbf{t}}=\left(1, x_{t 1}, \ldots, x_{t p}\right)^{\prime}=\left(1, y_{t-1}, \ldots, y_{t-m}, z_{t 1}, \ldots, z_{t n}\right)^{\prime}\right)$, and $u_{t}$ denotes 
a sequence of independent identically distributed errors. $G$ denotes a continuous transition function, usually bounded between 0 and 1 . Because of these properties, the model cannot only explain the two extreme states, but also a continuum of states that lies between these two extremes. The slope parameter $\gamma>0$ is an indicator of the speed of transition between 0 and 1 , whereas the threshold parameter $c$ points to where the transition takes place. The transition variable $s_{t}$ is usually one of the explanatory variables or the time trend.

Teräsvirta (1998) explains in detail several popular STR models, especially logistic (LSTR) models and exponential (ESTR) model. The functional forms of the transition function in these models are as follows:

$$
\text { 1. LSTR1 Model: } G_{1}\left(\gamma, c ; s_{t}\right)=\frac{1}{1+e^{-\gamma\left(s_{t}-c\right)}},
$$

$G_{1}$ is a monotonously increasing function of the transition variable $s_{t}$, ranging from 0 to 1 . Additionally, $G_{1}(\gamma, c ; c)=0,5$ therefore, we can say that the threshold parameter represents the point of transition between the two extreme regimes with $\lim _{s_{t} \rightarrow-\infty} G_{1}=0$ and $\lim _{s_{t} \rightarrow \infty} G_{1}=1$. The restriction $\gamma>0$ is an identifying restriction. As we can see from Figure 1, the slope parameter $\gamma$ indicates how rapidly the transition of $G_{1}$ from 0 to 1 takes place. While a moderate value of $\gamma=1$ imposes a slow transition, the function where $\gamma=10$ changes quite fast.

Figure 1

LSTR1 Transition Functions with $c=1$

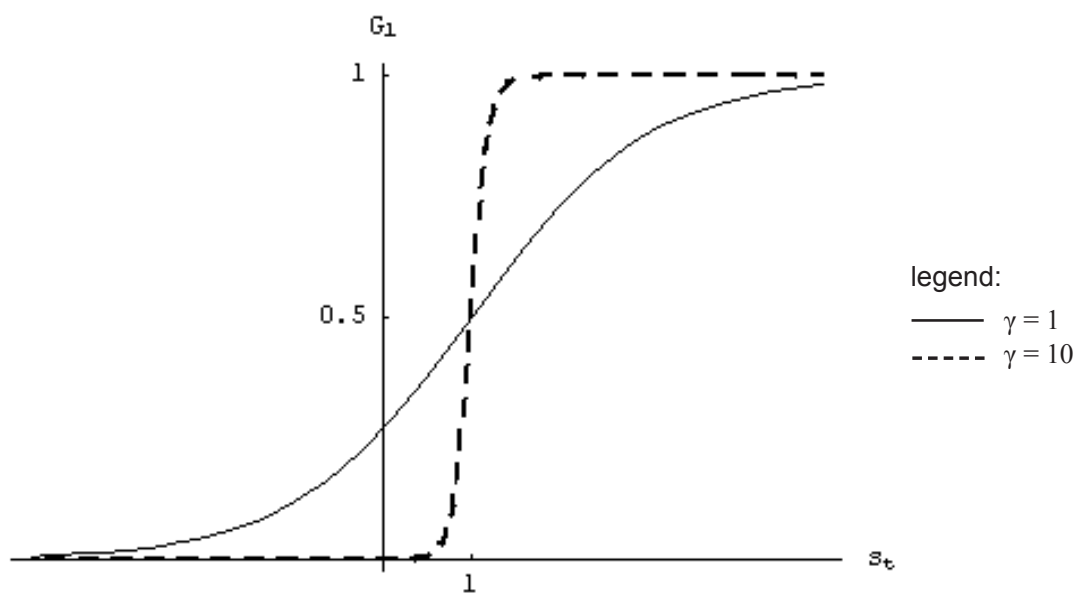

2. LSTR2 Model: $G_{2}\left(\gamma, c_{1}, c_{2} ; s_{t}\right)=\frac{1}{1+e^{-\gamma\left(s_{t}-c_{1}\right)\left(s_{t}-c_{2}\right)}}$

Monotonous transition may not always be satisfactory in application. The quadratic logistic function in the LSTR2 model is a non-monotonous transition function that is especially useful in the case of reswitching. $G_{2}$ is symmetric about the point $\frac{c_{1}+c_{2}}{2}$ 
and $\lim _{s_{t} \rightarrow \pm \infty} G_{2}=1 . G_{2}$ is never equal to 0 ; its minimal value lies between 0 and 0.5 . Two examples of the function $G_{2}$ with different values of the parameters are depicted in Figure 2 below.

3. ESTR Model: $G_{3}\left(\gamma, c ; s_{t}\right)=1-e^{-\gamma\left(s_{t}-c\right)^{2}}$

Sometimes it is desirable that small absolute values in the transition variable are related to small values of the transition function. The ESTR model with an exponential transition function complies with the above condition if $c=0$. The function $G_{3}$ is non-monotonous and symmetric about point $c$.

Both the LSTR2 model and the ESTR model enable reswitching, but they differ in the rapidity of reswitching. One can see from Figure 3 that for a large value of $\gamma$, the transition of $G$ from 1 to 0 and back to 1 is much faster for the ESTR model as compared to the LSTR2 model, where the reswitching can be slower when the gap between $c_{1}$ and $c_{2}$ is large.

Figure 2

LSTR2 Transition Functions with $c_{1}=-1$ and $c_{2}=2$

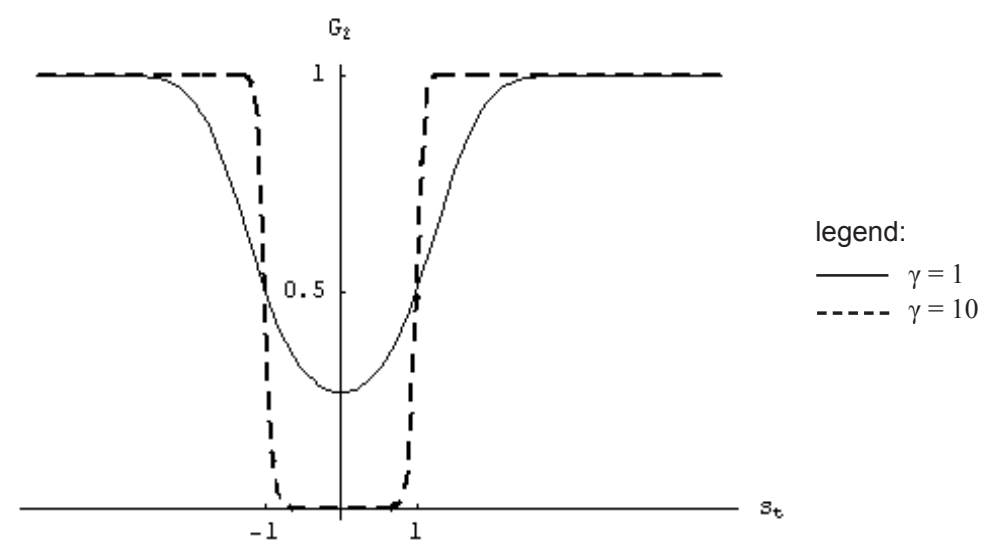

Figure 3

ESTR Transition Functions with $c=0$

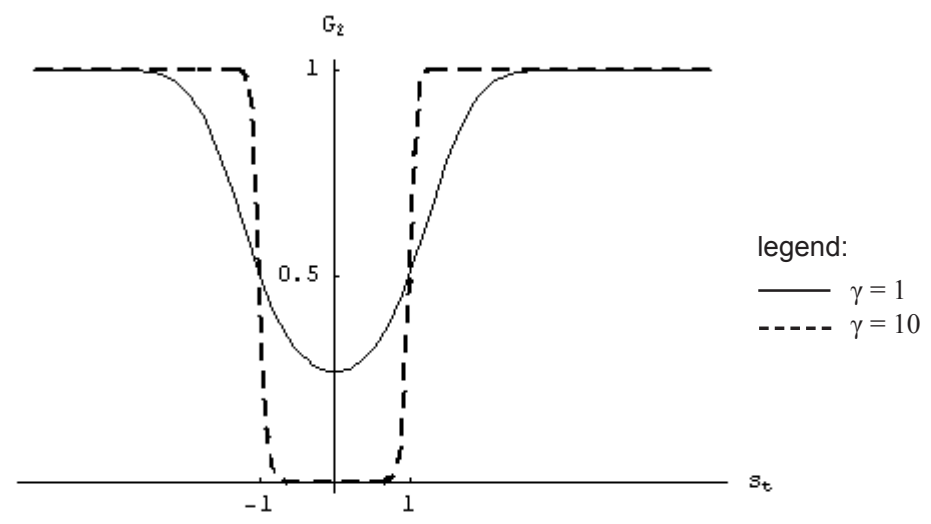




\subsection{Testing linearity against STR}

Let us start by defining a more convenient notation: $G_{i}^{*}=G_{i}-0.5$ for $i=1,2$ and $G_{3}^{*}=G_{3}$. Obviously, $G_{i}^{*}=0$ for $\gamma=0$. The null hypothesis of linearity for model (1) can be expressed as $H_{0}: \gamma=0$ against $H_{1}: \gamma>0$ or as $H_{0}^{\prime}: \boldsymbol{\theta}=0$ against $H_{1}^{\prime}: \boldsymbol{\theta} \neq 0$. This indicates an identification problem, as model (1) is identified under the alternative but not identified under the null hypothesis. Namely, the parameters $c$ and $\boldsymbol{\theta}$ are nuisance parameters that are not present in the model under the null hypothesis and whose values do not affect the value of the log-likelihood. Consequently, the likelihood ratio test, the Lagrange multiplier and the Wald test do not have their standard asymptotic distributions under the null hypothesis and one cannot use these tests for consistent estimation of the parameters $c$ and $\boldsymbol{\theta}$. To overcome this problem, Luukkonen, Saikkonen and Teräsvirta (1998) replaced the transition function with its Taylor approximation of a suitable order. The first order Taylor approximation around $\gamma=0$ for the logistic transition function $\mathrm{G}_{1}^{*}$ is of the form:

$$
T_{1}=a_{0}+a_{1} s_{t}+R_{1}\left(\gamma, c ; s_{t}\right) .
$$

$R_{1}\left(\gamma, c ; s_{t}\right)$ is the remainder term obtained from the Taylor's theorem. After replacing $G_{1}^{*}$ by $T_{1}$ in equation (1), one obtains

$$
y_{t}=\mathbf{x}_{\mathbf{t}}^{\prime} \mathbf{b}_{\mathbf{0}}+\left(\mathbf{x}_{t}^{\prime} s_{t}\right) \mathbf{b}_{\mathbf{1}}+u_{t}^{*},
$$

where $\mathbf{b}_{0}$ and $\mathbf{b}_{1}$ are $(p+1)$-dimensional column vectors of parameters and the null hypothesis of linearity can be expressed as $H_{0}^{\prime \prime}: \mathbf{b}_{1}=0$ against $H_{1}^{\prime \prime}: \mathbf{b}_{1} \neq 0 . H_{0}^{\prime \prime}$ can be tested by a straightforward Lagrange multiplier test. The test statistic is asymptotically $\chi^{2}-$ distributed with $p+1$ degrees of freedom. We have to emphasize that auxiliary regression (3) is suitable only if the transition variable is not an element of the vector $\mathbf{x}_{\mathbf{t}}$. Otherwise, the variable $s_{t}$ appears twice on the right-hand side of equation (3). The problem is solved by substituting $\mathbf{x}_{\mathbf{t}}$ with $\tilde{\mathbf{x}}_{\mathbf{t}}=\left(x_{t 1}, \ldots, x_{t p}\right)^{\prime}$ in the second term of (3).

To avoid problems with low power in some special cases, a third order Taylor polynomial is usually applied. This leads to the following auxiliary regression:

$$
y_{t}=\mathbf{x}_{\mathbf{t}}^{\prime} \mathbf{b}_{\mathbf{0}}+\left(\mathbf{x}_{\mathbf{t}}^{\prime} s_{t}\right) \mathbf{b}_{\mathbf{1}}+\left(\mathbf{x}_{\mathbf{t}}^{\prime} s_{t}^{2}\right) \mathbf{b}_{\mathbf{2}}+\left(\mathbf{x}_{\mathbf{t}}^{\prime} s_{t}^{3}\right) \mathbf{b}_{\mathbf{3}}+u_{t}^{*} .
$$

Additionally, the F-version of the test is preferred because of its better small sample properties. A comprehensive discussion of these issues can be found in Teräsvirta (1998) and in Luukkonen, Saikkonen and Teräsvirta (1998).

\subsection{Model specification}

If the null hypothesis of linearity is rejected for several potential transition variables, Teräsvirta (1998) suggests selecting the variable with the strongest rejection of linearity (i.e. with the smallest $\mathrm{p}$-value). This is a heuristical procedure, but nonetheless successful in practice. Next, one has to determine the type of transition function. The decision rule is based on the following sequence of nested hypotheses that test for the order of polynomial in variable $s_{t}$ in auxiliary regression (4): 


$$
\begin{gathered}
H_{04}: b_{3}=0 \\
H_{03}: b_{2}=0 \mid b_{3}=0 \\
H_{02}: b_{1}=0 \mid b_{2}=b_{3}=0
\end{gathered}
$$

The F-tests for testing the above hypotheses are denoted by F4, F3, and F2, respectively. Provided that the hypothesis $H_{03}$ is the one with the strongest rejection, an LSTR2 or an ESTR model is indicated as the best choice due to properties of the coefficients in auxiliary regression (4). A detailed technical derivation and explanation can be found in Granger and Teräsvirta (1993). If the hypothesis $H_{02}$ or $H_{04}$ is the one with the strongest rejection, Granger and Teräsvirta (1993) suggest choosing an LSTR1 model. The STR modelling technique is described in detail in Teräsvirta (1998).

\subsection{Misspecification tests}

The misspecification tests were first developed by Eitrheim and Teräsvirta (1996) for a univariate time series, i.e. for smooth transition autoregressive (STAR) models, but the generalization to STR models is straightforward. Three tests are usually performed, namely the test of no error autocorrelation, the test of no remaining nonlinearity and the parameter constancy test. For a detailed description of these tests, see Eitrheim and Teräsvirta (1996) and Lin and Teräsvirta (1994).

\section{Empirical Analysis}

A comprehensive overview of recent advances in the use of nonlinear time series models in empirical finance is given by Franses and van Dijk (2002). The authors devote an entire chapter to regime-switching models for stock returns. To arrive at appropriate model specifications in the spirit of the described theoretical suggestions, we relied on the work by Franses and van Dijk (2002) and on the empirical analysis of Aslanidis (2002). The following variables were employed in our study as possible predictors for the monthly returns of the Slovene stock exchange index SBI 20 (sbi): rate of inflation (infl), gross domestic product $(\mathrm{gdp})$, broad money $(\mathrm{m} 3)$, short-run interest rate $(r)$ and stock market indices S\&P $500(s p)$ and FTSEurofirst $100(f t s e)$. Variable names are stated in brackets. The SBI 20 index is published by Ljubljana Stock Exchange and provides information about the performance of the entire regulated Slovene stock market. Rate of inflation is a monthly rate calculated from the consumer price index. Since January 2007, when Slovenia adopted EURO, the M3 variable is calculated as the contribution of Slovenia to the money aggregate M3 of the European monetary union. The FTSEurofirst 100 index comprises the 60 largest companies by market capitalisation in the FTSE Developed Europe Index and 40 additional companies selected for their size and sector representation. It was chosen for a measure of the price development of Eurozone and UK equities, while the S\&P 500 index is representative of the US stock market. Plots of SBI 20 and its returns are given in Figure 4. 
Figure 4

Plots for the Slovene Stock Exchange Index (SBI 20) and Its Returns

SBI 20

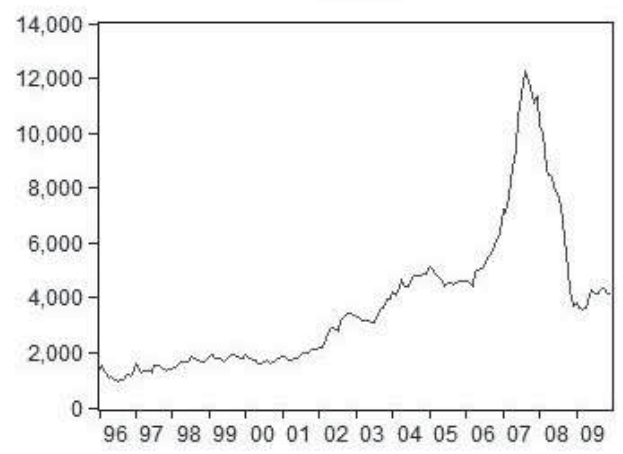

SBI 20 returns

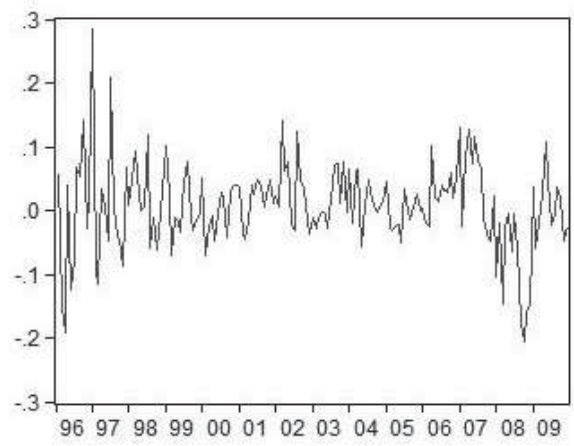

Monthly data for the period from January 1996 till December 2009 were obtained from the Bank of Slovenia, from the Statistical Office of the Republic of Slovenia, from the Yahoo Finance Database and from the FTSEurofirst Index Homepage (http://www. ftseurofirst.com/). Since Slovenia declared independence in June 1991 and introduced its own currency (tolar) in October of the same year, we only used data from January 1996, when the tolar was already an established currency. All calculations were performed with the help of EViews and Gauss software.

In a preliminary specification, we examined the linear relationship. This simplifies the search for an appropriate nonlinear specification. Firstly, unit root tests were applied to variables in logs and all of the variables turned out to be I(1). Therefore, the first differences in the variables in logs were employed in the study as stationary growth rate variables and the prefix $d l n$ - was added to variable names. For example, $d l n g d p$ stands for the first difference of the logarithm of the GDP variable. The variable infl is an exception to this rule. Since the rate of inflation was already a stationary variable, the level variable was used in our study.

The lag order of the model was determined with the help of the information criteria, with the maximal lag length set to 12. The Akaike information criterion selected a model of lag order 12 and the Schwarz criterion a lag order 3 . Our choice was a parsimonious model of lag order 3 augmented with the first and eleventh lag of the SBI 20 returns to deal with autocorrelation. After the insignificant variables were removed, the OLS estimates (as given in Table 1 below) were obtained.

The results of the Breusch Godfrey LM test in Table 1 do not indicate autocorrelation, nor is there any evidence of heteroskedasticity or ARCH effects. The obtained linear equation also proved satisfactory after being tested for the normality of errors, but the CUSUM of squares test in Figure 5 indicates problems with parameter constancy. Figure 6 depicts recursive coefficient estimates in the linear equation. Sudden changes in the course of the recursive estimates imply structural change, whereas smooth changes hint at misspecification. In our case, the coefficients $\mathrm{C}(7)$ and $\mathrm{C}(8)$ of the $d \ln r_{t-3}$ and $d l n s b i_{t-1}$ variables displayed the most variation. The relationship under observation is thus a candidate for nonlinear STR specification, since several coefficients do not seem to be constant over time. 
Table 1

Estimated Linear Model

\begin{tabular}{|c|c|c|c|}
\hline \multicolumn{4}{|c|}{ Dependent variable: $d l n s b i_{t}$} \\
\hline \multicolumn{4}{|c|}{ Included observations: 156 after adjustments } \\
\hline Variable & Coefficient & Std. Error & p-value \\
\hline Const & -1.398670 & 0.746199 & 0.0629 \\
\hline infl $_{t-1}$ & 0.013959 & 0.007423 & 0.0620 \\
\hline dlnftse $_{t-1}$ & 0.156411 & 0.077143 & 0.0444 \\
\hline$d I n s p_{t-1}$ & 0.309564 & 0.103303 & 0.0032 \\
\hline$d l n g d p_{t-3}$ & 0.712060 & 0.200496 & 0.0005 \\
\hline$d \operatorname{lnm} 3_{t-3}$ & -0.547311 & 0.146244 & 0.0003 \\
\hline$d \ln r_{t-3}$ & -0.169269 & 0.083494 & 0.0444 \\
\hline$d l n s b i_{t-1}$ & 0.244333 & 0.092055 & 0.0088 \\
\hline$d I n s b i_{t-11}$ & 0.198996 & 0.064376 & 0.0024 \\
\hline R-squared & 0.364478 & \multicolumn{2}{|c|}{ Diagnostic tests (p-values) } \\
\hline S.E. of regression & 0.052203 & Jarque -Berra & 0.0837 \\
\hline Log likelihood & 243.8877 & White (cross terms) & 0.1041 \\
\hline AIC & -3.011381 & $\begin{array}{l}\text { Breusch Godfrey } \\
\text { (12 lags) }\end{array}$ & 0.1535 \\
\hline BIC & -2.835427 & ARCH LM (12 lags) & 0.1480 \\
\hline
\end{tabular}

Figure 5

CUSUM of Squares Test

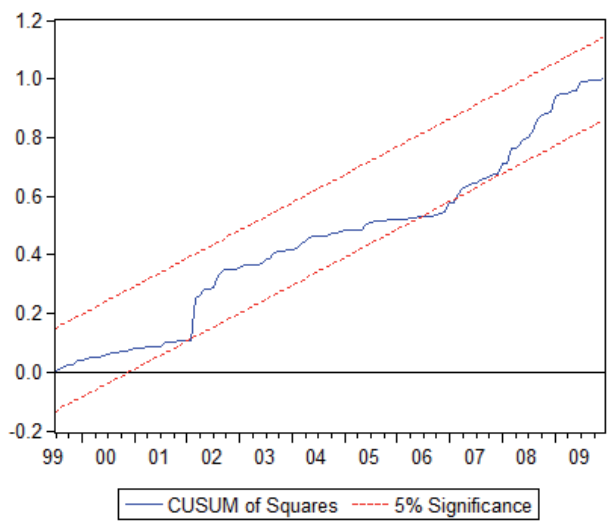

Empirical results obtained by the linear model suggest that the returns of the stock exchange indices S\&P 500 and FTSEurofirst 100 influence the Slovene stock exchange index returns pro-cyclically within 1 month. Christiansen and Ranaldo (2008) found strong persistency effects for New EU Member States, and that there were significant global linkages with stock markets in old EU countries in terms of returns, volatility, 
and co-exceedances. As a second conclusion, we could state that the structure of the stock exchange index and the structure of the financial sector portfolio of securities influence the pro-cyclical reaction of stock exchange indices. A seasonal component is indicated by a positive relationship between the Slovene stock exchange index returns and their lagged value after a time period of one and eleven months.

According to our model, the nominal value of securities accommodates to inflation with a time lag of one month, which could be understood as inflation inertia. The results are also in accordance with the hypothesis of pro-cyclicality between nominal GDP and the stock exchange index described above (Borio and Lowe, 2002).

\section{Figure 6}

\section{Recursive Coefficient Estimates (following coefficients in Table 1 row-wise)}
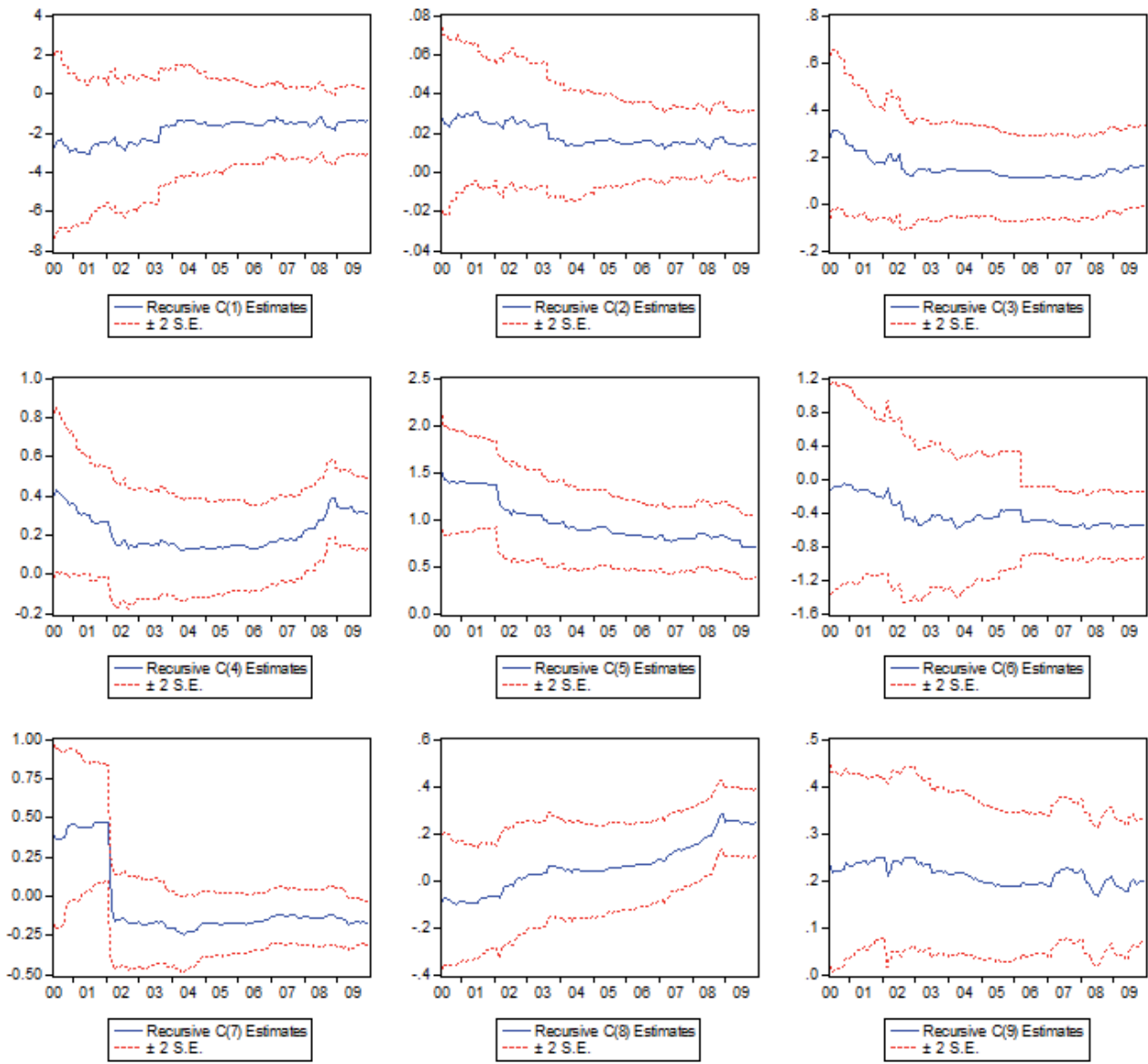

The equation is now subjected to linearity tests. All independent variables may be considered as suitable candidates for a transition variable. From Table 2 test results, we obtained a set of suggested transition variables for which the null hypothesis of linearity could be rejected. The variable with the smallest p-value of the linearity test (i.e. F-test in 
the second column of Table 2) is chosen for the transition variable. In our case, the lagged GDP growth variable $d \ln g d p_{t-3}$ is the one with the strongest rejection of linearity. After the transition variable has been selected, the type of the transition function is determined with the help of the sequence of nested hypotheses (F4, F3 and F2 tests), as explained in Section 3.2. Since for the transition variable $d \operatorname{lng} d p_{t-3}$ the F2 test is the one with the smallest p-value, the LSTR1 model is indicated as the best choice.

Table 2

Linearity Test Results (p-values)

\begin{tabular}{|l|c|c|c|c|}
\hline Variable & F & F4 & F3 & F2 \\
\hline time $_{\text {trend }}$ & 0.0438 & 0.2889 & 0.0148 & 0.4074 \\
\hline inft $_{t-1}$ & 0.2476 & 0.3265 & 0.4605 & 0.1321 \\
\hline dlnftse $_{t-1}$ & 0.7476 & 0.5885 & 0.5987 & 0.5539 \\
\hline dInsp $_{t-1}$ & 0.0346 & 0.0890 & 0.3497 & 0.0351 \\
\hline dlngdp $_{t-3}$ & 0.0286 & 0.6812 & 0.0325 & 0.0198 \\
\hline dlnm3 $_{t-3}$ & 0.2498 & 0.4788 & 0.0182 & 0.9280 \\
\hline dlnr $_{t-3}$ & 0.0690 & 0.0454 & 0.7213 & 0.0632 \\
\hline dlnsbi $_{t-1}$ & 0.1178 & 0.8613 & 0.2153 & 0.0111 \\
\hline dlnsbi $_{t-11}$ & 0.0659 & 0.3367 & 0.0963 & 0.0841 \\
\hline
\end{tabular}

The exponent of the transition function is usually scaled by the standard deviation of the transition variable. In this way, $\gamma$ becomes a scale-free parameter. Due to occasional problems with the convergence of the nonlinear optimization procedure, some experimentation to find appropriate starting values was required. The final set of estimates for the parameters of the nonlinear equation can be found below. The model satisfactorily passed the diagnostic checking. A comparison of the linear and nonlinear model reveals an increase in $R^{2}$ from 0.364 to 0.437 and a decrease in the standard error of regression from 0.052 to 0.049 . The estimate of the slope parameter $\gamma$ is large (116.91) and indicates a rapid transition from one extreme regime $(G=0)$ to another $(G=1)$.

The rather high standard error of $\gamma$ should not be interpreted as a sign of weak nonlinearity. Accurate estimation of $\gamma$ is not always feasible, as it requires many observations in the immediate neighbourhood of the threshold parameter $c$ (Teräsvirta, 1998). In addition, large changes in $\gamma$ have only a small effect on the shape of the transition function. Figure 7 depicts the plot of transition function against time and the scatter plot of transition function against transition variable. Since the threshold parameter $c$ is equal to 0.0044 , the extreme regimes can be characterized by negative or low GDP growth for $G=0$ and by high GDP growth for $G=1$. 


\section{Equation 6}

Estimates for the STR Equation (with standard deviations given in brackets) and diagnostic tests (with p-values given in brackets)

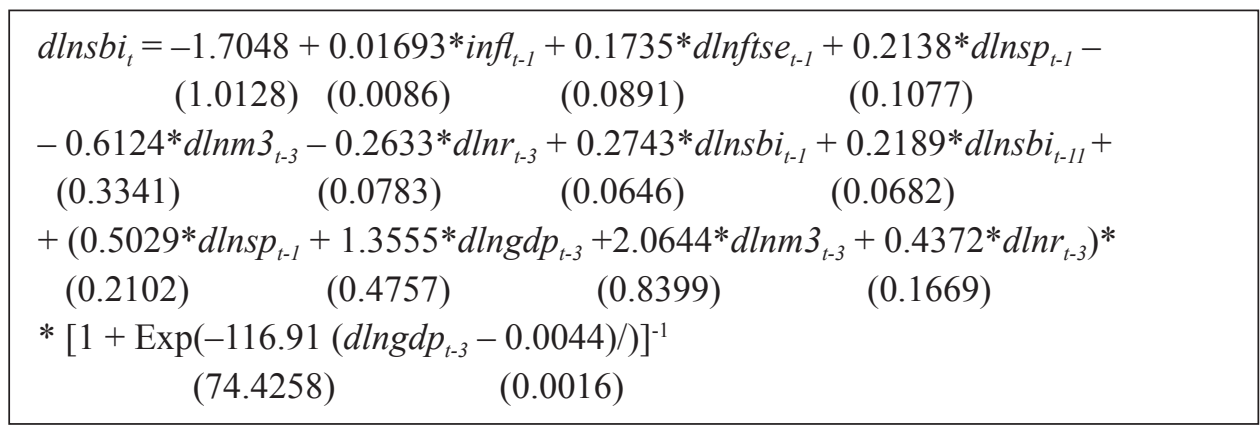

$\mathrm{T}=156, \mathrm{R}^{2}=0.437$, S.E. $=0.049, \mathrm{JB}=5.204(0.074)$

$\operatorname{AR~LM~}(1)=1.309(0.255), \operatorname{AR~LM~}(4)=0.928(0.450), \operatorname{AR~LM}(8)=1.361(0.227)$ $\operatorname{ARCH~LM}(1)=0.438(0.646), \operatorname{ARCH} \operatorname{LM}(4)=0.293(0.882)$,

ARCH LM (8) $=0.317(0.959)$

Param. const. lin. $=1.292(0.242)$, Param. const. nl. $=1.605(0.129)$

Notes: AR LM (8) denotes the no remaining error autocorrelation test (with no autocorrelation up to 8 lags under the null hypothesis). The ARCH LM (8) notation is analogous. The param. const. lin. refers to the LM3 test for the constancy of parameters in the linear part of the equation and param. const. nl. in the nonlinear part (see Lin and Teräsvirta (1994) for details).

The two extreme regimes are determined by equations:

$$
\begin{aligned}
& d \text { lnsbi } i_{t}=-1.7048+0.01693 * \text { inf }_{t-1}+0.1735 * \text { dlnftse }_{t-1}+0.2138 * \text { dlnsp }_{t-1}- \\
& -0.6124 * d \operatorname{lnm} 3_{t-3}-0.2633 * d \ln r_{t-3}+0.2743 * d \ln s b i_{t-1}+0.2189 * d \ln s b i_{t-11} \\
& \text { for } G=0 \text { and by equation } \\
& d \operatorname{lnsbi} i_{t}=-1.7048+0.01693 * \text { inf }_{t-1}+0.1735 * d \operatorname{lnftse} e_{t-1}+0.7167 * d \operatorname{lnsp} p_{t-1}+ \\
& +1.3555 * d \operatorname{lng} d p_{t-3}+1.4520 * d \operatorname{lnm} 3_{t-3}+0.1739 * d \ln r_{t-3}+ \\
& +0.2743 * \text { dlnsbi }_{t-1}+0.2189 * d \ln s b i_{t-11} \\
& \text { for } G=1 \text {. }
\end{aligned}
$$

According to our nonlinear model, we can say that there is a difference between the regimes of high GDP growth on one hand and low or negative GDP growth on the other hand. Andersen et al. (2004) argue that the equity markets react differently to the same news depending on the state of the economy, with bad news having a positive impact during expansions and the traditionally-expected negative impact during recessions. The authors document important contemporaneous linkages across all markets and countries over-and-above direct news announcement effects. Meanwhile, the asymmetry of output growth decreases the correlation of stock returns according to Morgado and Tavares (2006). 
Figure 7

Transition Function Plotted against Time and the Scatter Plot of Transition Function against Transition Variable
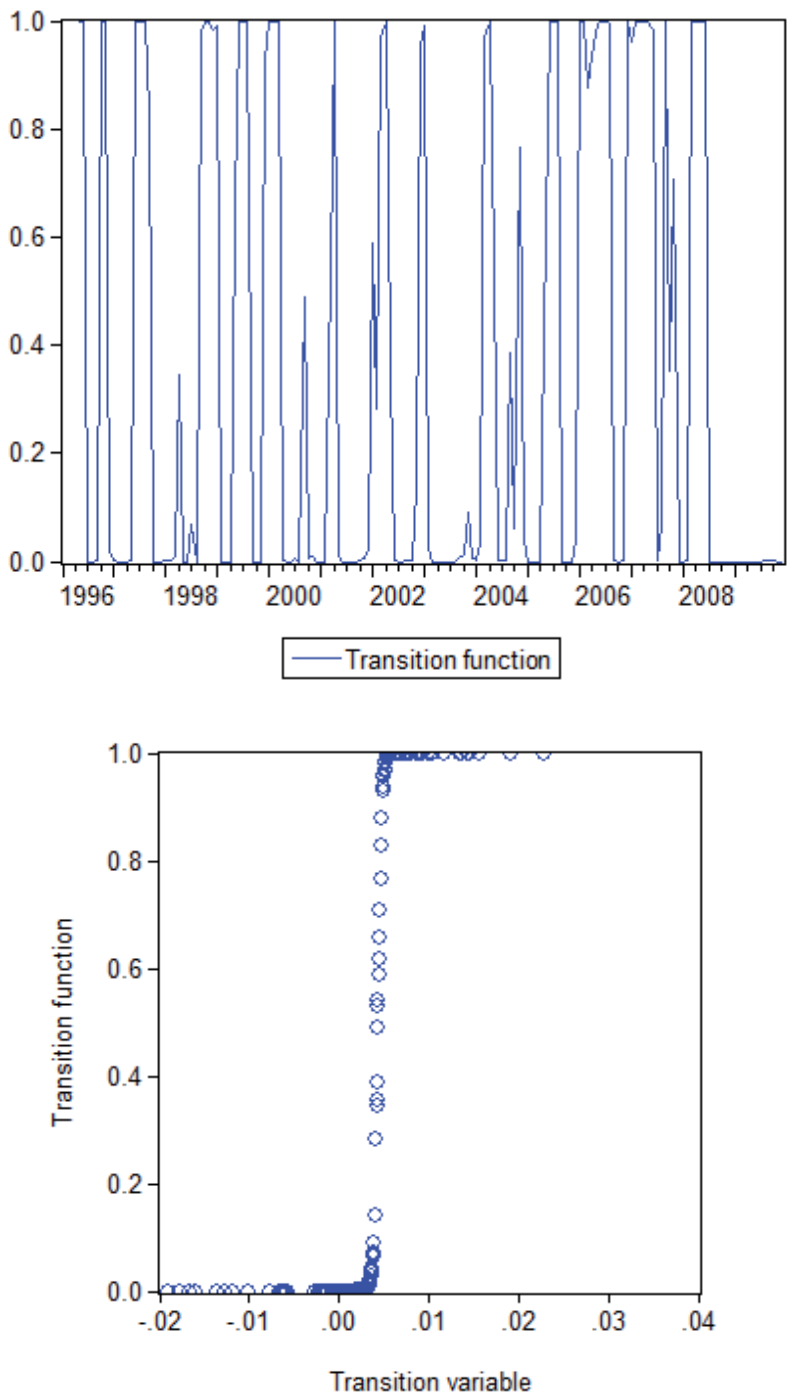

In the regime of low GDP growth, we confirmed the low positive effect of the FTSEurosfirst 100 and S\&P 500 index returns on the Slovene stock exchange index returns, with a time lag of one month. The impact of the lagged SBI 20 returns is positive and higher than the impact of both foreign index returns. In the regime of low GDP growth, we proved a positive influence of inflation and negative influence of interest rates. Cumhur et al. (2005) uncovered unidirectional strong volatility spillover from inflation and interest rates on all stock price indices. According to Luintel and 
Paudyal (2006) all pairs of stock and retail price indices are cointegrated and common stocks hedge against inflation. The findings appear theoretically more plausible because nominal stock returns must exceed the inflation rate to insulate tax-paying investors.

Knif et al. (2008) showed that depending on the economic state, positive and negative inflation shocks could produce a variety of stock market reactions. The effect of inflation on stock returns is conditional on whether investors perceive inflation shocks as good or bad news in different economic states. According to Adams and McQueen (2004) unexpected increases in both the producer price index and the consumer price index cause stock prices to fall. The strength of the relationship is stronger for large stocks when the economy is strong (i.e. the economy is operating near capacity) and the news are bad. The dependency on the length of the return window, the size of the stock, the strength of the economy, and the type of inflation news, helps explain why researchers have found different answers to the question.

According to the nonlinear model, the returns of the S\&P 500 index have a stronger influence on SBI 20 returns in times of high GDP growth. According to Cumperayot et al. (2006) extreme events on stock markets are much more interrelated globally, with events in the USA having the strongest impact worldwide. Hartmann et al. (2003) even argue that, on the global stock markets, spill over of extreme events does occur, but only from America to countries in Europe and Asia.

Maysami et al. (2004) conclude that the stock market forms a cointegrating relationship with changes in interest rates, money supply, industrial production, price levels and exchange rate. The equities' price movements induced by interest rates and M3 money stock are different in both regimes of our model. The impact of interest rate and M3 money stock on the stock exchange index returns depends on the information about inflation and the perception about nominal interest rate dynamics as good or bad news. Zafar (2008) revealed that stock returns have a negative and significant relation with interest rates. His results depict that interest rates have a strong predictive power for stock returns, but weak predictive power for volatility. In the extreme conditions of overheating of the economy and depression, the usual confirmed correlation of the interest rate with stock index returns does not work, owing to the uncertainty that stems from financial crisis and the role of monetary policy in this time period. Government and central banks respond with unprecedented fiscal stimulus, monetary policy expansion and institutional bailouts (Guillen, 2010). This result supports the idea that uncertainty stems from monetary policy.

\section{Conclusion}

We proposed a smooth transition regression model to explain Slovene stock exchange index returns employing financial and macroeconomic variables. The pro-cyclical dynamics of GDP growth and the returns of the FTSEurofirst 100 and S\&P 500 indices with Slovene stock exchange index returns has been confirmed. According to the nonlinear model, the reaction of SBI 20 returns to employed explanatory variables depends on the magnitude of GDP growth. In the regime of low or negative GDP growth, we have proven the low positive effect of the returns of the FTSEurosfirst 100 and S\&P 500 indices on Slovene stock exchange index returns. In the regime of high GDP growth, the S\&P 500 index returns were found to have a higher 
influence on SBI 20 returns. During different GDP growth regimes, the dynamics of global financial markets impact the Slovenian stock exchange with varying intensity. The weaker relationship between Slovene stock exchange index returns and S\&P 500 returns in the period of lower or negative GDP growth could be explained by less developed financial markets in Slovenia and therefore not closely linked interchange of securities.

\section{References}

Adams, G., McQueen G. (2004), "The Effects of Inflation News on High Frequency Stock Returns." The Journal of Business, 77 (3): pp. 547-574.

Anatolyev, S. (2006), Nonparametric Retrospection and Monitoring of Predictability of Financial Returns. Moscow: Centre for Economic and Financial Research at New Economic School.

Andersen, G. T., Vega C., Bollerslev T., Diebold F. X. (2004), "Real-Time Price Discovery in Stock, Bond and Foreign Exchange Markets." National Bureau of Economic Research (NBER) Working Paper, No. 04-028.

Aslanidis, N., Osborn R. D., Sensier M. (2002), "Smooth Transition Regression Models in UK Stock Returns." University of Crete, Department of Economics, Working Paper, No. 0201.

Babetskii, I., Komárek L., Komárková Z. (2007), "Financial Integration of Stock Markets among New EU Member States and the Euro Area." Finance a úvěr - Czech Journal of Economics and Finance 57: pp. 7-18.

Bae, K. H., Karolyi G. A., Stulz R. M. (2003), "A New Approach to Measuring Financial Contagion." Review of Financial Studies 16: pp. 717-763.

Baltzer, M., Cappiello L., De Santis R. A., Manganelli S. (2008), "Measuring Financial Integration in the New EU Member States." European Central Bank, Occasional Paper Series, No. 81.

Bechev, I. (2003), "Efficient Market Hypothesis: Budapest, Prague and Warsaw Stock Exchange." Available at: [http://papers.ssrn.com/sol3/papers.cfm?abstract_id=625901], (25. 8. 2010).

Bernanke, B. (1983), "Nonmonetary Effects of the Financial Crisis in Propagation of the Great Depression." American Economic Review 73 (3): pp. 257-76.

Borio, C. E., Lowe P. (2002), "Asset Prices, Financial and Monetary Stability: Exploring the Nexus." Bank for International Settlements, BIS Working Papers, No. 114.

Borio, C. E., Furfine C., Lowe P. (2001), "Procyclicality of the Financial System and Financial Stability: Issues and Policy Options," in Marrying the Macro and Micro-Prudential Dimension of Financial Stability. Bank for International Settlements, No. 1, pp. 24-31. Available at: [http://www.bis.org/ publ/bppdf/bispap01a.pdf]. (25. 8. 2010).

Boyd, J., Levine, R. and Smith, B. (2001), "The Impact of Inflation on Financial System Performance." Journal of Monetary Economics 47 (2): pp. 221-248.

Brandmeier, M. (2006), "Reasons for Real Appreciation in Central Europe," in Discussion Paper No. 55, May, pp. 396-400. Centre for Globalization and Europeanization of the Economy. Available at: [http://www.cege.wiso.uni-goettingen.de/Dokumente/55_Brandmeier.pdf], (13. 8. 2009).

Breuss, F. (2003), "Balassa-Samuelson Effect in CEEC. Are there Obstacles for Joining the EMU?" in Working Papers No. 52, May. Vienna: IEF, Institute Vienna. Available at: [http://www.univ-paris13. fr/CEPN/coudert_5_balassa.pdf], (13. 8. 2009).

Chan, K. S., Tong, H. (1986), "On Estimating Thresholds in Autoregressive Models." Journal of Time Series Analysis 7: pp. 179-190.

Cappiello, L, Kadareja, G. A., Manganelli, S. (2006), "Financial Integration of New EU Member States." European Central Bank, Working Paper Series, No. 683. 
Chelley-Steeley, P. L. (2005), "Market Equity Integration Using Smooth Transition Analysis: a Study of East European Stock Markets." Journal of International Money and Finance 24: pp. 818-831.

Christiansen, C., Ranaldo A. (2008), "Extreme Co-exceedances in New EU Member States' Stock Markets." Swiss National Bank, Working Paper 2008/10.

Claessens, S., Djankov, S., Klingebiel, D. (2005), "Stock Markets in Transition Economies." Financial Sector Discussion Paper, No. 5, September. The World Bank.

Cumhur, E., Arslan C. K., Erdem M. S. (2005), "Effects of Macroeconomic Variables on Istanbul Stock Exchange Indexes." Applied Financial Economics 15 (14): pp. 987-994.

Cumperayot, P., Keijzer T., Kouwenberg R. (2006), "Linkages between Extreme Stock Market and Currency Returns." Journal of International Money and Finance 25 (3): pp. 528-550.

Černý, A. (2004), "Stock Market Integration and the Speed of Information Transmission." CERGE-EI Working Paper Series, No. 242.

Dvorák, T., Podpiera R. (2006), "European Union Enlargement and Equity Markets in Accession Countries." Emerging Markets Review 7 (2): pp. 129-146.

Égert, B., Koubaa Y. (2004), "Modelling Stock Returns in the G-7 and in Selected CEE Economies: a Non-Linear GARCH Approach." William Davidson Institute, Working Paper, No. 663.

Égert, B., Kočenda E. (2007), "Interdependence between Eastern and Western European Stock Markets: Evidence from Intraday Data." Economic Systems 31 (2): pp. 184-203.

Eitrheim, O., Teräsvirta, T. (1996), "Testing the Adequacy of Smooth Transition Autoregressive Models." Journal of Econometrics 74 (2): pp. 59-76.

Festić, M., Repina, S. (2009), "Financial Stability in the Baltics." Finance a úvěr - The Czech Journal of Economics and Finance 59 (6): pp. 554-576.

Franses, P. H., van Dijk, D. (2002), Nonlinear Time Series Models in Empirical Finance. Cambridge: Cambridge University Press.

Garrett, I., Spyrou S. (1999), "Common Stochastic Trends in Emerging Equity Markets." The Manchester School 67 (2): pp. 649-660.

Gelos, G, Sahay R. (2000), "Financial Market Spillovers in Transition Economies." International Monetary Fund, No. 71/2000. Washington: IMF.

Gilmore, C. G., Lucey, B. M., McManus, G. M. (2008), "The Dynamics of Central European Equity Market Co-movements." Quarterly Review of Economics and Finance 48: pp. 605-622.

Goetz, V. P. (2004), "Asset Prices and Banking Distress: a Macroeconomic Approach." Basel, BIS Working Paper, No. 167, pp. 23-26.

Goetzmann, W. N., Li L., Rouwenhorst K. G. (2005), "Long-Term Global Market Correlations." Journal of Business 78 (4): pp. 1-38.

Granger, C. W. J., Teräsvirta, T. (1993), Modelling Nonlinear Economic Relationships. New York: Oxford University Press.

Guillen, J. (2010), "Financial Distress and Access to Capital in Emerging Markets." Prague Economic Papers, 2010(1): pp. 5-20.

Harrison, B., Moore, W. (2009), "Stock Market Co-movement in the European Union and Transition Countries." Financial Studies 3: pp. 2-28.

Hartmann, D., Pierdzioch C. (2006), "Nonlinear Links between Stock Returns and Exchange Rate Movements." Munich Personal RePEc Archive (MPRA) Paper, No. 558. Available at: [http:// econpapers.repec.org/paper/pramprapa/558.htm]. (25.8.2010).

Hartmann, P., Straetmans S., de Vries, C. G. (2003), "The Breadth of Currency Crises." Working Paper, University of Maastricht.

Horobet, A., Ilie L. (2007), "On the Dynamic Link between Stock Prices and Exchange Rates: Evidence from Romania." Munich Personal RePEc Archive (MPRA) Paper, No. 6429.

Horská, H. (2005), "Český akciový trh - jeho efektivnost a makroekonomické souvislosti." Finance a úvěr - The Czech Journal of Economics and Finance 55 (56): pp. 283-301. 
Kim, S. J., Moshirian, F., Wu, E. (2005), "Dynamic Stock Market Integration Driven by the European Monetary Union: an Empirical Analysis." Journal of Banking and Finance, 29: pp. 2475-2502.

Knif, J. J., Kolari, J., Pynnönen S. (2008), "Stock Market Reaction to Good and Bad Inflation News." Journal of Financial Research 31 (2): pp. 141-166.

Lin, C. F., Teräsvirta T. (1994), "Testing the Constancy of Regression Parameters against Continuous Structural Change." Journal of Econometrics 62 (6): pp. 211-228.

Luintel, B. K., Paudyal K. (2006), "Are Common Stocks a Hedge against Inflation?" Journal of Financial Research 29 (1): pp. 1-19.

Luukkonen, R., Saikkonen P., Teräsvirta T. (1998), "Testing Linearity against Smooth Transition Autoregressive Models." Biometrika 75: pp. 491-499.

Maysami, R., Howe, C. L., Hamsah, M. A. (2004), "Relationship between Macroeconomic Variables and Stock Market Indices: Cointegration Evidence from Stock Exchange of Singapore's all-sector indices." Journal Pengurusan 24: pp. 47-77.

Moore, T., Wang P. (2007), "Volatility in Stock Returns for New EU Member States: Markow Regime Switching Model." International Review of Financial Analysis 16: pp. 282-292.

Morgado, P., Tavares J. (2006), "Economic Integration and the Co-movement of Stock Returns." CEPR, Discussion Paper, No. DP6519.

Pistor, K. (2000), "Patterns of Legal Change: Shareholder and Creditor Rights in Transition." Working paper, No. 49, London, European Bank for Reconstruction and Development.

Rajkowski, M. (2008), "To What Extent Price Movements on the Warsaw Stock Exchange are Correlated with Trends on the International Financial Markets?" Available at: [http://ssrn.com/ abstract=1097117]. (25.8.2010).

Swan, P., Westerholm, P. J. (2006), "Market Architecture and Global Exchange Efficiency." Working Paper, The University of Sydney and the University of New South Wales. Available at: [http:// papers.ssrn.com/sol3/papers.cfm?abstract_id=891579], (25.8.2010).

Syllignakis, M., Kouretas G. (2006), "Long and Short-Run Linkages in CEE Stock Markets: Implications for Portfolio Diversification and Stock Market Integration." William Davidson Institute, Working Papers Series, No. 832.

Teräsvirta, T. (1998), "Modelling Economic Relationships with Smooth Transition Regression," in Handbook of Applied Economic Statistics. New York, Marcel Dekker, pp. 507-572.

Wang, P., Moore, T. (2008), "Financial Market Integration for the Transition Economies: Dynamic Conditional Correlation Approach." Birmingham Business School and Coventry University. Available at: [www.business.bham.ac.uk/events/papers/P_Wang.pdf], (25.8.2010).

Westermann, F. (2004), "Does the Euro Affect the Dynamic Interactions of Stock Markets in Europe? Evidence from France, Germany and Italy." The European Journal of Finance, 10: pp. 139-148.

Zafar, N., Urroj, S. F., Durrani, T. K. (2008), "Interest Rate Volatility and Stock Return and Volatility." European Journal of Economics, Finance and Administrative Sciences 2008(14): pp. 135-140. 